\title{
クモ膜下出血後の髄液循環動態
}

-RI-cisternographyによる検討一

\author{
朝長 正道・沢田 稔夫・岳野 圭明 - 田中彰 \\ 福島 武雄・佐野 吉德・城 邦男*
}

\section{Study of CSF Dynamics after Subarachnoid Hemorrhage with RI-cisternography}

\author{
Masamichi Tomonaga, Toshio Sawada, Yoshiaki Takeno, Akira Tanaka, \\ Takeo Fukushima, Yoshinori Sano and Kunio Jyo* \\ Department of Neurosurgery, Fukuoka University \\ * Department of Radiology, Fukuoka University
}

\begin{abstract}
Summary
We have studicd CSF dynamics after subarachnoid hemorrhage (SAH) and normal pressure hydrocephalus (NPH) with the morphological alternation of the intracranial distribution of RI and clearance of intracranial RI.

The radionuclide used was $1 \mathrm{mCi}$ of ${ }^{169} \mathrm{Yb}-\mathrm{DTPA}$. Scintiphotos of the head were taken at 1, 3, 6, 24, 48 and 72 hours after RI injection into the lumbar intrathecal space, and clearance curves were made by plotting the time (seconds) required for 50,000 counts when each scintiphoto was taken. The curve showed an initial descending part representing increase in radioactivity in the head, followed by an ascending part representing loss of radioactivity. The materials studied were 123 RI-cisternographies applied to 88 cases of SAH, of which 72 were ruptured aneurysm. The remaining 16 cases were primary SAH. Normal control study was made on 20 cases of epilepsy, minor head injury and cerebral infarction. Morphological changes of scintiphotos were classified into 2 major groups, i.e., ventricular retention of RI (within 24 hours and beyond 24 hours), and subarachnoid block(unilateral and bilateral). The clearance curve also changed in 2 ways; one was a tendency of a shift in the base of the curve to the right, i.e. delay in establishing maximum counting rate, and the other was a decrease of ascending gradient after the base of the curve. These changes in clearance curve seemed to represent disturbance of CSF circulation and absorption. CSF dynamics after SAH were evaluated along with the patients' condition and RI-cisternographical changes, and the conclusions were as follows:
\end{abstract}

1. RI-cisternographical changes take 3 weeks after SAH to become stable, therefore, this examination should be done after this 3 week period.

2. Intracranial surgery of aneurysm does not influence CSF dynamics on RI-cisternography.

3. Ventricular retention of RI beyond 24 hours suggests NPH, even more so when combined with bilateral subarachnoid block.

4. RI-cisternography should be repeated on a patient suspected of NPH because ventricular retention within 24 hours and beyond 24 hours changes each other according to improvement or deterioration of the clinical features.

5. RI-cisternography is a most useful and safe tool both for evaluation of CSF dynamics after SAH and for diagnosis of NPH, which is definitely represented by ventricular retention of RI beyond 48 hours and by bilateral

福陆大学徆神経外科

*福岡大学放射線科

〔連絡先： $\mathbf{\top} 814$ 福岡市西区七隈 34 , 福刖大学脳神経外科, 朝長正道〕

1977 年 8 月 2 日 受稿 
subarachnoid block. However, accurate diagnosis and treatment of suspected NPH cases should be made by a comprehensive study of other examinations such as saline infusion test, pneumoencephalography and EEG.

Key words: RI-cisternography, clearance curve, subarachnoid hemorrhage, cerebral aneurysm, normal pressure hydrocephalus

\section{Iはじめに}

クモ膜下出血（以下 $\mathrm{SAH}$ と略す）が髄液循環動態老 変化させ，複雜な病像を呈して原病を修旍することは上 〈知られている。特化正常压水頭症（以下 NPH と略

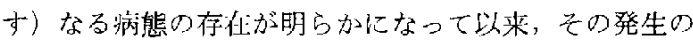

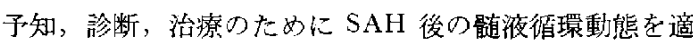
確に把握することが重要になってきた。この目的には RI-cisternography がもっとも有用で，多くの報告があ り，特にNPH の際の形態学的可見についてはほぼ一致 した知見が述べられている。このような形態上の所見は 個々の齿例について評価寸ることはできるが，SAH後の 娟液㽞環動態を種々な臨床的分類に従って比較検討し， 一般的な変化の流れ上して捉えることはむずかしい，我 々はSAH 患者の RI-cisternography 在形態学的所見のみ ならず,クリアランスカープで定量的, 客観的に検討し， $\mathrm{SAH}$ 後の檤液循環動態の総体的な変化を知り，個々の 症例特に NPII の診断や RI-cisternography の評洒传資 することを試みた。

\section{III対象および方法}

SAH 88例に行わ机た123国の RI-cisternography 考娭 討した.この88例中72例が脳動脈瘤であり，5ち9例が 多発性動脈瘤であった，動脈溜の全数は81個，前大畝動 脈瘤27，中大䑈動脈瘤22，内頚動脈瘤20，椎骨動脈痹12 である．多発性動脈瘤を出血源と考えられるもので分類

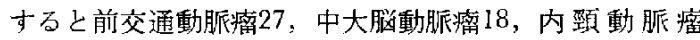
20, 椎骨動脈熘 7, 計72例上なる。残り16例は原因不明 の primary SAH 群である (Table 1).

SAH 急性期症例に対しては RI-cisternography は必䫇 ではないし，また本法施行による再出血の危険もあると

Table 1 Case material of SAH

$$
\text { SAH }
$$

88 cases

$\begin{array}{lr}\text { Aneurysm } & \\ \text { Ant. Comm. A. } & 27 \\ \text { Mid. Cereb. A. } & 18 \\ \text { Int. Carot. A. } & 20 \\ \text { Vert-Basil. A. } & 7\end{array}$

Primary SAH
考え，急性期症例は対象としなかった，また雮動静脈奇 形与除外している

正常対照群として神経学的に正常で，脑血管写，気脳 写にも異常のない軽症頭部外傷, てんかん, 脎梗塞など 20例の RI-cisternography 定選んだ．

腰椎穿刺索行い,ク王膜下腔に ${ }^{169} \mathrm{Yb}$ DTPA $1 \mathrm{mCi}$ 注入した後， $1 ， 3 ， 6 ， 24 ， 48 ， 72$ 時間目にがンマカメ ラた撮影し形態学的検討を加え，また各時間每 $の$ anterior viewで50,000カウントに要する秒数を用いてクりア ランスカーブを作製した，撮影に際してクリスタル面は 患者に圧迫感を与えない程度に顔面にできるだけ近す け，患者每に一定とした。コリメーターは410 KeV，視 野径 $370 \mathrm{~mm}$ ，ホール数 1,200 でり，使用したエネルギ ーピークは198 KeVであり, 常に補正し, window 幅は $\pm 15 \%$ で測定した。 また50,000カウントとカウント数至 一定にして撮影したので RI decay は実際上問題になら ないと考えた。

\section{III 結 果}

RI-cisternographyの形態学的所見を次のよ5に分類し tc.

(1) 正常群

(2) 脳室停滞群

(ventricular retention，以下 VRと略す).

a. 24時間以内消失群 (以下 VRa と略可)。

b. 24 時間以上停滞群 (以下 VRb と略す).

(3) 毛膜下腔閉塞群

(subarachnoid block, 以下 $\mathrm{SAB}$ 上略す).

a. 片側性 (以下 $\mathrm{SABa}$ と略寺).

b. 両側性（以下 $S \wedge \mathrm{Bb}$ と略す）。

止常で仕 RI は注入後 $1 \sim 3$ 時間で大槽から脳底部, さらに一部はシルビウス裂に達し，6時閣目にはシルビ ウス裂から脳表扔よざ半球間の媨槽が造影され，24時間 目に注大脳半球表面特に上矢状洞周辺に集積してくる。 48時間後には譄表の RI activity は明ら加に低下する (Fig. 1 top).VR 群は多くの場合, 注入 3 時間後汇は 大槽から再側側脳室が造影され，6時間目にかけて増 強する。民の後24時間目に加けて急速に消失していく VRa 上, 24時間後与脳室内に RI が停滞している VRb に尔けられる，VRbの中にも，その後次第に減少するむ のや，72時間以上明らかに残存寸るものなどがある 
後の急性期や，状態の悪い症例に注本検查を施行しなが ったためであるう。

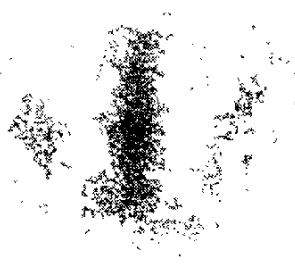

クリアランスカーブの所見は次の上らに分けられた。

(1) 正常群

(2) 最低值時間遅延群

(3) 立ち上り楥徐群

正常では Table 2 および Fig. 2 のように 1 時間值か 亏 3 時間， 6 時間目々急速に秒数が減少し， 6 時間值が 最低值を示す。このことはタモ膜下腔内でのRI の移動 上吸収が進行する中で，頭蓋内に存在する RI がもっと も多いことを意味し，特に吸収部一達寸るまでの移動の 速さを表わするのと思われる。すなわちこの最低值の時 間が㧍くれる(2)群はクモ膜下腔あるい脳室内人の移動 に障害があると考えられる。6 時問目に最低值に達した 後，正常では RI の吸収速度に比例して24㭙間，72時間 上秒数が增加し，カーブは急上昇していくここのカーブ の立ち上りが緩やかに心る(3)群では，クモ膜下腔あるい は媨室からの RI 吸收が障害されていると思われる。

Table 2 RI-cisternographic data from 20 control patients

\begin{tabular}{lrrrrrr}
\hline & 1 & 3 & 6 & 24 & 48 & 72 hrs. \\
\hline Maximum & 857 & 650 & 474 & 604 & 799 & 1330 \\
Minimum & 503 & 236 & 164 & 210 & 512 & 767 \\
\hline Mean & 659 & 324 & 243 & 378 & 632 & 1068 \\
SD & 108 & 112 & 97 & 118 & 94 & 166 \\
\hline
\end{tabular}

Value is second number required for 50,000 counts.

Fig. 1 Typical anterior R I-cisternograms.

Top: Normal figure

Middle: Ventricular retention

Bottom: Unilateral subarachnoid block

(Fig. 1 middle).SAB 群には局所性または片側性の)閉 塞所見を示す $\mathrm{SABa}$ と，びまん性また注雨側性の $\mathrm{SABb}$ に分计られ后 (Fig. I bottom).

RI の䫒蓋内人の上昇がないいわ方 non-filling は, 我ヶの症例には兄られなからた。これは㧍そらく発作直

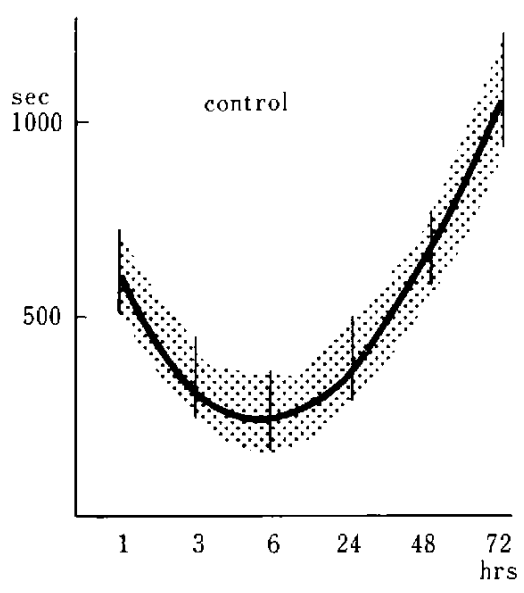

Fig. 2 Clearance curve of intracranial radioisotope (1). Figure shows mean \pm 1 SD obtained from 20 control patients without $\mathrm{SAH}$ or hydrocephalus. 
Table 3 Ventricular retention and SAH frequency

\begin{tabular}{|c|c|c|c|c|c|}
\hline \multirow{2}{*}{$\begin{array}{l}\text { Number } \\
\text { of SAH } \\
\text { attack }\end{array}$} & \multicolumn{4}{|c|}{ Ventricular retention } & \multirow{2}{*}{ Tolal } \\
\hline & None & $\begin{array}{c}\text { Within } \\
24\end{array}$ & $\begin{array}{c}\text { Beyond } \\
24\end{array}$ & $\begin{array}{l}\text { Beyond } \\
48 \text { hrs. }\end{array}$ & \\
\hline 1 & 23 & 21 & 16 & 6 & 66 \\
\hline \multirow[t]{2}{*}{$\begin{array}{l}\text { More } \\
\text { than! }\end{array}$} & 5 & 5 & 5 & 7 & 22 \\
\hline & 28 & 26 & 21 & 13 & 88 \\
\hline
\end{tabular}

Table 4 Subarachnoid block and location of aneurysm

\begin{tabular}{lrrrr}
\hline \multirow{2}{*}{$\begin{array}{l}\text { Location } \\
\text { of } \\
\text { aneurysm }\end{array}$} & \multicolumn{3}{c}{ Subarachnoid block } & \\
\cline { 2 - 4 } & None & $\begin{array}{c}\text { Uni- } \\
\text { lateral }\end{array}$ & $\begin{array}{l}\text { Bi- } \\
\text { lateral }\end{array}$ & Total \\
\hline Ant. Comm. A. & 7 & 10 & 10 & 27 \\
Mid. Cereb. A. & 2 & 16 & 0 & 18 \\
Int. Carot. A. & 3 & 12 & 5 & 20 \\
Vert-Basil. A. & 5 & 1 & 1 & 7 \\
Primary SAH & 12 & 3 & 1 & 16 \\
\hline & 29 & 42 & 17 & 88 \\
\hline
\end{tabular}

88例中, RI が脳室へ逆流寸るVR 群は60例で,この 5 ち24時間以内に消失するVRa 群が26例, それ以上停 滞するVRb 群が34例であった(Table 3)。これら各群 のクリアランスカーブを比較するとVR(一) 群とVRa 群では最低值は6時間目で，その後の立ち上りにも差が みられない，しかし VRb 群では最低值が24時間の方向 一移行し，カーブも緩やが上昇する(Fig. 3 left col一 umn).

クモ膜下腔の閉塞所是走示す $\mathrm{SAB}$ 群は59例で，42例 が片側性の SABa，残り17例が雨側性を示す SABbであ った (Table 4).このらち SABa 群のクリアランスカー ブに洔徴的な所見は見られなか力たが， $\mathrm{SABb}$ 群のも のはその脳室逆流の所見に平行した変化があった。

VR と SABbとには相関関係があり，䈪室内停滞が長

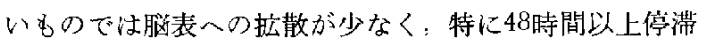
例では畄表への移行がまったくないか，きかめて少ない ものが多加った，脳室内停滞加短い例では，脳室逆流と 脳表への移行像が混在してみられたり，东ず脳室が造影 され，遅れて脑表八移行するものもあった。

$\mathrm{SAH}$ 回数上脳窒逆流上の関係は Table 3 より明らか のよらに，1回発作群心はVR(一)群 $34.8 \%$, VRa 群 $31.8 \% ， V R b$ 群 $33.4 \%$ あるるのに対し，2回以上発作群
はそれぞれ $22.7 \% ， 22.7 \% ， 54.6 \%$ となり長特間停滞例 が増加する。16例の primary SAH 群は形態上もクリア シンスカーブも正常所見を示した. しかし動脈溜群のク リアランスカーブ经最低值時間がやや遅れ，立ち上りが 緩やかとなる傾向があり，特に22例の 2 回以上出血群で は著明となり，50例の1回出血群とは明らかな差がみら れ当 (Fig. 3 right column).

クモ膜下腔閉塞恃 Table 4 の上5に前大脑動脈，中大 脳動脈，内顾動脈领域群に高率に丸られた，前大脳動脈 領域群では片側あるい情側の開塞ず同数ずつにあり， 中大脳動脈群で注出系源となった勳服瘤側のみに片側性 に現れ，内頸動脈群は多く汢破裂側に双られるが，両側 性のこともあった。これに対して椎骨脳低動脈領域群上 primary SAH 群では閉寒所見のないものが多かった。 出血部位とクリアランスカーブには特に相関は見出せな 加长 (Fig. 4 top).

SAH 発作汃らの経過時間と䯣液循環動態上の関係を 知るため，11例の発作後 3 週以内の群と77例 3 週以降 の群に分けてクリアランスカーブを作り検討した. 3 週 以内の比較们急性期に行かれたものは正常群に近い力ー ブを描くのに対して，3週以降群では立ら上りが緩やか たあった (Fig. 4 middle).

開頭術による影響を知るため，動脈瘤直接手術をはさ んで約 1 力月の間隔で RI-cisternography が施行された 19例について検討したが，形態上でもタリアランスカー ブでも術前，術後に明らかな変化尘見出すことはでさな bったた (Fig. 4 bottom)

知能障害が認められたるのは19例である。この全例に 絾室の抾大ł゙血管写で確認されている，また RI の脳室 逆流はVRa が1例のみで，他の18例はVRbと長時閒 停湿例であった。

一方 VRb 群34例中18例に知能障菁があることにな 9， RI の脳室内長時間停滞上知能障害との密接な関逨 性がうかがわれた，史た血管写上脳室㹡大があったもの は24例で，SAH 88例中の27\%にあたる. そしてこの中 の19例に知能障害があることになり，残りの 5 例仗VRa

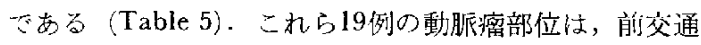
動脈瘤 11 例, 内頸動脈瘤に腷内血腫索伴亏も03 例, 媨

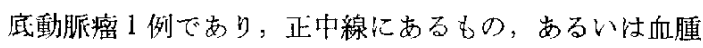
が存在したものなどの重症例であった。

高度の知能障卦, 神経学的所見, RI-cisternographyに よる脳室逆流, クモ膜下腔閉塞所見および臨床的経邀よ り， NPHが強く疑加た 9例には1力月〜1年8力月 の期間に2 24 回の本検查が行われ，7例に V-P shunt が施行された（Table 6). 5ち6 例は1〜2力月間隔一゙ 

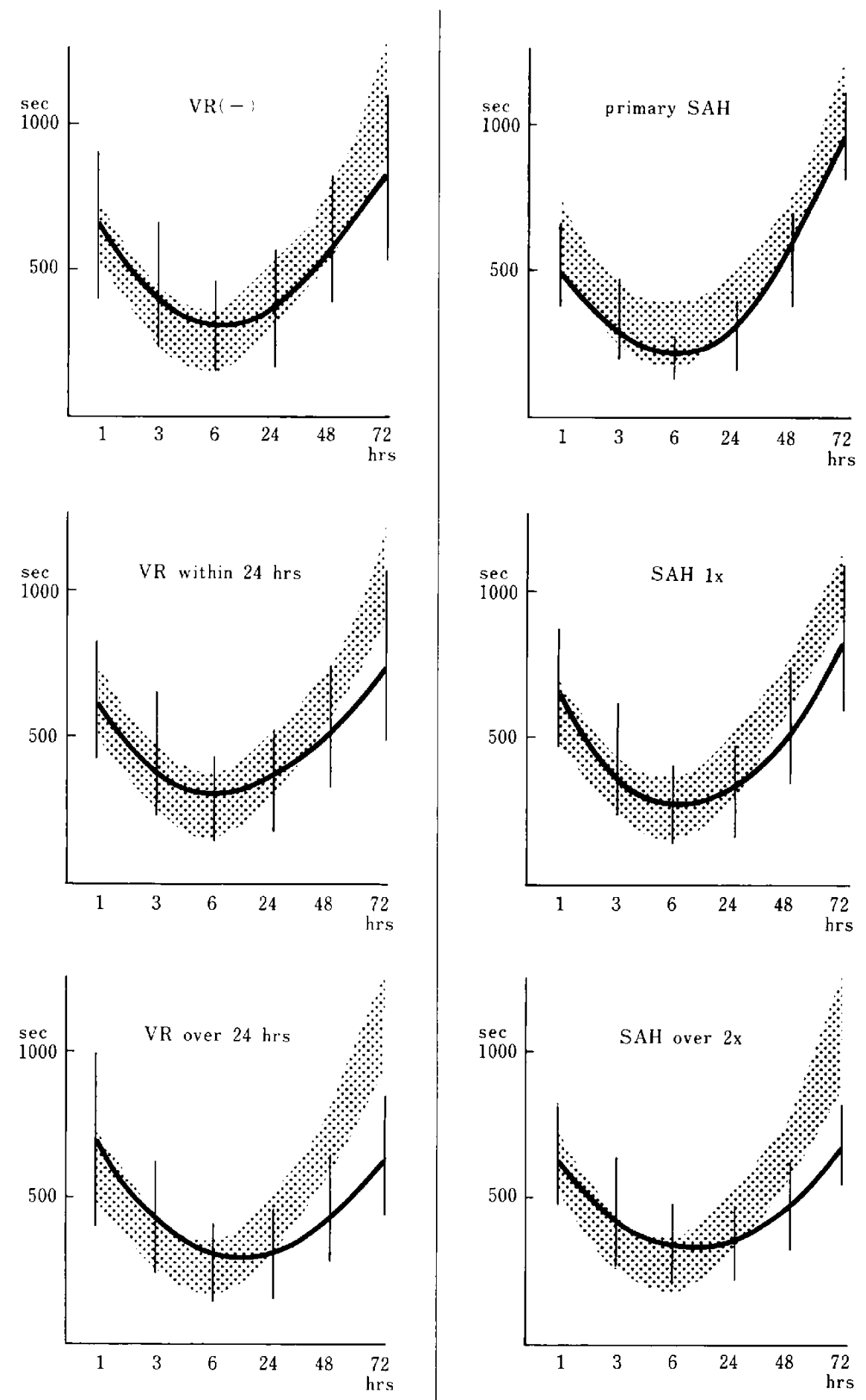

Fig. 3 Clearance curve of intracranial radioisotope (2). Comparison among patients without ventricular reflux, with ventricular retention within $24 \mathrm{hrs}$. and beyond $24 \mathrm{hrs}$. (right column), and primary SAH, 1 and more than 1 attack of aneurysmal rupture (left column). Shaded area is a range of mean \pm 1 SD of control study. 

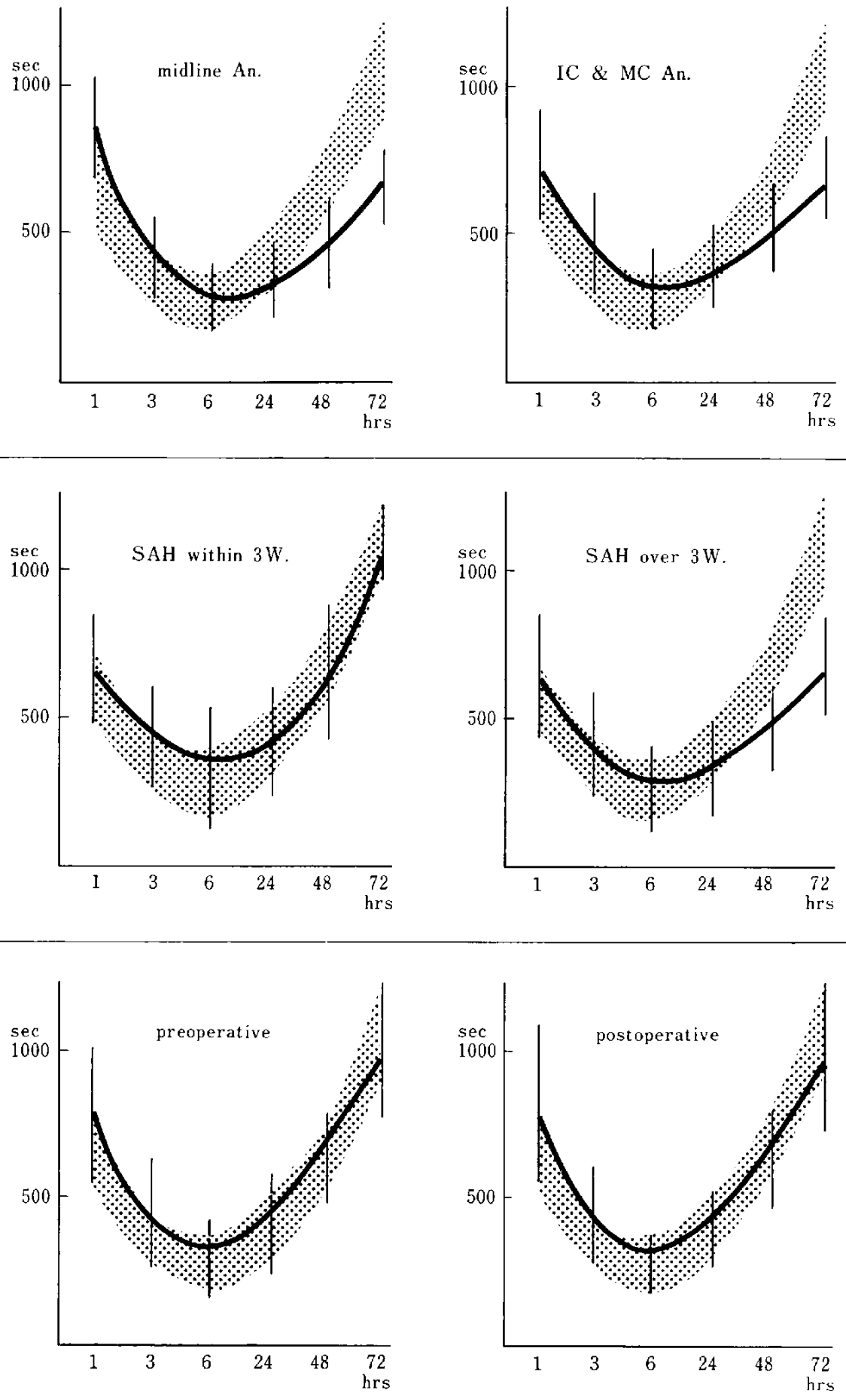

Fig. 4 Clearance curve of intracranial radioisotope (3). Comparison between midline and lateral aneurysm (top), patients within 3 weeks and beyond 3 weeks after SAH (middle), and preoperative and post-operative study in same patients (bottom). Shaded area is a range of mean $\pm 1 \mathrm{SD}$ of control study. 
Table 5 Mentality and ventricular retention of 24 cases with hydrocephalus

\begin{tabular}{ccc}
$\begin{array}{c}\text { Ventricular } \\
\text { retention }\end{array}$ & \multicolumn{2}{c}{ Mentality } \\
\cline { 2 - 3 } Within 24 hrs. & 5 & 1 \\
Beyond 24 hrs. & 0 & 18 \\
\hline
\end{tabular}

行われた本检查の異常所見に変化がなく shunt 手術の適 灾と考えられたが，VRaの3 例巾2例には saline infusion test を行い手術適応の決定に資した，他の1例は約 1 年間の経過の5ち数回の检查が行われ，タモ膜下腙閣 塞所見には変化势ないが，骫室内逆流がVRaからVRb 一移行し，臨床症状も増悪したためV-P shuntを施行し

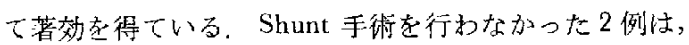
1 年 4 力月, 1 年 8 力月の間に数回の検査をくり返し, クリアランスカーブ, 脑表クモ膜下腔の閉塞所見とも変 化はないが，畝室内逆流が VRb から VRa 八短縮し： 同時に臨床症状の改善もみられたものである。

\section{IV 考察}

RI-cisternography は髄液话環動態を比較的簡便かつ安 全に，しかb生理的状態て正確に知りらる検查法であ る。本法は DiChiro?3 が1964年にその有用性について報 告して招り，媨神経外科領域では種々な疾患の病態解明 や補助診断法として広く行われるよらになり，きわわて 有用な検查としてその地位を確立してきた。一方 SAH が骮液循環に大さな影響を与えることは周知てあり， shunt 手街によって良く回復するいわゆる NPHが， $\mathrm{SAH}$ の後にかなりの頻度に発生することが注目される ようになった。 そして，NPHの謋断や shunt 手術の適 応決定に RI-cisternography が有才」な指針を与えること

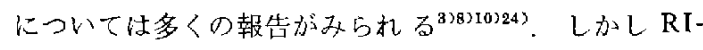
cisternography のみでは，その診断や治療方針決定に不 十分であることもよく知られている.

我々は $\mathrm{S} \Lambda \mathrm{H}$ 患者に行った RI-cisternography を形態

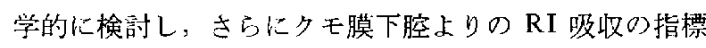
として，各測定時間の50,000カウントに要する秒数で作 ったクリアランスカーブを用い定量的に解析した。これ によって SAH 後の鹃液循㻴動態の変化とその時間的推 移在知り，本法加 NPH の予知や之の診断と治療方針決 定にどの上うに有用であるのか，加つ本法の限界はとら なのかなどについて考察する。

RI-cisternography の方法や使用核種, その正常像に ついては多くの発表や成書があり：ここで論ずる必要は ないと思放吕。

$\mathrm{SAH}$ 後の RI-cisternography の形態上の異常像は結果 の項に述べたように， RI の脳室逆流とクモ膜下腔閉塞 に大別される。脳室逆流は正常状態では起こらないと一 般に思われている(Rudd $\left.{ }^{21)}\right)$ 。しかし Kieffer ${ }^{13)}$ は正常と 思われる例でも $2 \sim 4$ 時間の脳室逆流が観察されること があるといい，また髄液犆環時間は個人差が大きく，正 常41例中 9 例は平均より早く，12例は逢延したが，24時 間までにはすぶて无常パターンに戻ったと報告してい る. 我々の症例中, VR(ー) 群は88例中28例であった。

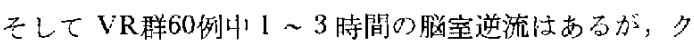
乇膜下腔閉塞もなく，以後仙まったく正常の RI-cisternography 所見走したものが primary SAH 1 例, 前交通 動脈瘤 1 例の 2 例市った。 RI の脳室逆流は多くの実験 的, 臨休的事実より ${ }^{1117}$, 髄液の脳室壁よりの吸収を示 すもので，たと充短時間です脳宝逆流所見は異常と考え るべきであり， RI の檤室停滞時閶は脳室よりの㵦液吸 收の齐率在表しているとも考えられる。VRa 群とVRb 群との間に性臨床上でも差があることは多くの人々が認

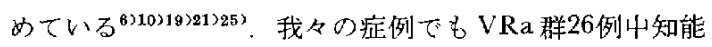

Table 6 Clinical data from patients with shunted NPH

\begin{tabular}{|c|c|c|c|c|c|c|c|c|c|c|c|}
\hline Case & Age & Sex & $\begin{array}{l}\text { Location } \\
\text { of } \\
\text { aneurysm }\end{array}$ & $\begin{array}{l}\text { Fre- } \\
\text { quency } \\
\text { of } \\
\text { SAH }\end{array}$ & $\begin{array}{l}\quad \text { Grade } \\
\quad \text { on } \\
\text { admis- } \\
\text { sion }\end{array}$ & $\begin{array}{l}\text { Mental } \\
\text { impair. }\end{array}$ & $\begin{array}{l}\text { Hydro- } \\
\text { cephal. }\end{array}$ & $\begin{array}{l}\text { Vent. } \\
\text { reten- } \\
\text { tion }\end{array}$ & $\begin{array}{l}\text { Sub- } \\
\text { arach. } \\
\text { block }\end{array}$ & $\begin{array}{l}\text { Interval } \\
\text { of } \\
\text { SAH- } \\
\text { Ope. }\end{array}$ & Result \\
\hline 1 & 58 & $\mathbf{M}$ & Ant Comm. A. & 1 & Ia & -+ & ++ & $24 \mathrm{hrs}$ & Bilat. & 2 mos. & Fair \\
\hline 2 & 49 & $\mathbf{M}$ & Basil. A. & 5 & Ia & -+ & ++ & $72 \mathrm{hrs}$ & Bilat. & 5 yrs. & Good \\
\hline 3 & 50 & $\mathbf{F}$ & Lt. IC-PC: & 2 & Ia & -+ & + & 24 hrs & Unilat. & 5 mos. & Excellent \\
\hline 4 & 44 & $\mathbf{F}$ & Ant. Comm. A. & 3 & la & $+T$ & -+ & $72 \mathrm{hrs}$ & Bilat. & 5 mos. & Excellent \\
\hline 5 & 56 & $\mathbf{F}$ & Ant. Comm. A. & 3 & Ia & ++ & ++ & $72 \mathrm{hrs}$ & Bilat. & 1.5 mos. & Excellent \\
\hline 6 & 65 & $\mathbf{M}$ & Ant. Comm. A. & 1 & II & $\div-$ & ++ & $24 \mathrm{hrs}$ & Bilat. & 2 mos. & Excellent \\
\hline 7 & 54 & $F$ & Ant. Comm. A. & 1 & Ia & ++ & $+t$ & 48 hrs & Bilat. & $1 \mathrm{mo}$ & Excellent \\
\hline
\end{tabular}


障害は 1 例のみであるが、VRb群34例中18例に知能障害 がみられている。この両群では夕リアランスカーブにむ 明らかな差がありこの上うにVRa 群，VRb群に分け ていくことは NPH の診断のための大きな規淮となるで あろ 5 .

RIの膗槽や脳表への移動の片側性るるい忹局所性障 害すな⿰七 $\mathrm{SABa}$ は多くの場合出血部位を示唆する所見 である、しかし正常例38例中12例に SABa 諗めたと いう Kieffer ${ }^{12}$ の報告もあり，我々の例でむ primary $\mathrm{SAH} 3$ 例に明らかな $\mathrm{SABa}$ を観察している.このこと 性往にクモ膜癒着をきたす何らかの頭蓋内病変加存在 したことを稜するものかもしれない，我々の脳動脈留 症例については Table 3 に示すとおりであり，動脈瘤の 部位によってそのパターンに違いがある。このようなタ モ膜下腔閉塞のパターン注膊槽の閉塞の程度, 䏚表よ りの吸收障害度, そして腷宝よりの财收度しの相関で決 められ, 出血部位, 出血量, 出血回数などが関与し, $\mathrm{SABa}$ から $\mathrm{SABb}$ へと重篤度を增していくものであろ 5 .

クモ膜下腔からの RI の吸收を知るたか血中 RI 濃 度や尿中排泄量を経時的に測定することもされてい

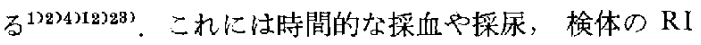
濃度测定の時間的制約，また RI の半減期や血中での滞 留時間などの問題があり，日常診断に簡便に応用でさる ものではない，我々恔各々の撮影時間で50,000カウント に要する秒数は，頭蓋内に存在する RI 量と反比例する 多のと考えて，これ在释時的にプロットし，クリアラン スカーブを作った。この方法は必ずしも正確とはいいが たい. 特にコリメーターの視野370 $\mathrm{mm}$ の中に頭部以外 の頚部，胸部が入る場合すなわち小昌では大きな誤差を 生じる可能性がある.しかしクモ膜下出血については対 象がすべて成人であるのでその愦差す小さく臨佅的には 十分用いらるものと考えられ，きわめて簡便であり，ま た形態学的な比較ができない種々な群の検討が可能であ る. $\mathrm{Curl}^{5)}$ ら性類似の方法を発表し, shunt 手術によっ て水頭症例のカーブが正常化すると述べている。動脈瘤 の部位による違い， $\mathrm{SABa}, \mathrm{SABb}$ と差などは RI 量を 頭蓋全体として测定しているので当然明らかではない。 しかし動脈㨨群は立ち上りが緩徐化するのに対し，pri一 mary SAH 群が正常曲楾を描くことは，動脈瘤の発見で きないSAH の経過が良いことを表すものであろう。ま た SAH 回数の増加とともに最低值時閒の遅延と立ち上

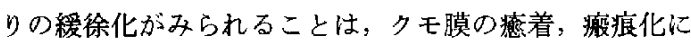
よる閉塞が SAHを重杖るごとに進行していくことを示 している、次に $\mathrm{SAH}$ 後 3 週までの群に比較して 3 週以
降の群で，最低值時間の遅延と立ち上り曲楾の緩徐化が 明らかになることは，クモ膜の癒着，瘦痕が完成するの に执よそ3週間を要寸ることを示唆しているものである 5，そしてこのことは後述寸るよ 5 SAH 後 NPI が 発症するまでの期間ともほぼ一致する所見である。

$\mathrm{SAH}$ 後の㵦液循環動態の変化を RI-cisternography 同一患者で追跡した報告は少ない，我々が行った術前， 街後の検査結果加らは動脈瘤直接手術は髄液循環動態に 新たな恋化を与えないことが加かった。これは頙微鏡手 術に上る庇護的な手使操作のためであるら。

また NPH が短われた症例の追跡調查では形態上も夕 りアランスカープでも変化がないむのが多く，この上う な症例に注 shunt 手術が有勃であった。しかし監床症状 の推移と相関してVRa から VRb 几変化し, クリアラ ンスカーブです最低值時間の遈延がみられたり，あるい は逆にVRbから VRa 几改善されたりした症例があ る、このよらな結果から，一たび完成されたクモ膜癒着 ひいてはクモ膜下腔閉塞湾化しがたいものであり，

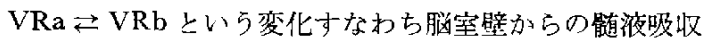
状態が臨床症状の増悪, 改善に大きく関与していること がすかる。

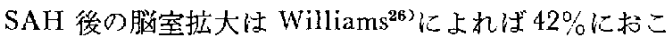
り，我々の症例でも27\%にみられている。立た NPHの 発生頻度は Foltz ${ }^{82} 10 \%$ ，Galera ${ }^{93}$ 19\%，Yasargil ${ }^{28} 10 \%$ し報告されている．我々の88例中知能障害のあったもの は19例で，このうち最終的に NPH と診断し, shunt 手 術を施行したものは7例である。他は自然宽解したるの や, 器質的病変によると判断されたものである、SAH り NPH 発症までの期間について, Ojemann ${ }^{18)}$ は 3 週で 十分であろ5とし, Yasargil ${ }^{283}$ は 1 力月後にもっとも多 いといい, Shulman ${ }^{22)}$ \& $3 \sim 4$ 週とみている。この期閒 は我々のクリアランスカーブで3週を境としてそ拟以降 の群に RI の循環と吸収障害が明らかになる所見と一致

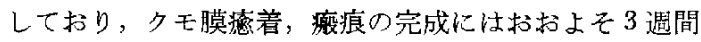
を要寸るものと思加る。動豚瘤部位と NPH 発生頻度 について Yasargil ${ }^{283}$ は前交通動脈瘤40\%，中大脳動脈瘤 $27 \%$, 内頸動脈瘤 $13 \%$ とし, $\operatorname{Rudd}^{21}$ も前交通動脈瘤に 多いと述べている，我々の例でも知能障害19例中 11 例， shunt 手術 7 例中 5 例が前交通動脈塯であった. 前交通 動脈瘤群のクモ膜下腔閉塞で両側性が半数であることは 他の部位の動脈瘤に比べて特異的であり，両側性閉塞を きたしやすいことが脑室逆流，NPH 発症と結びっいて いるものと思われる。血管写上脳室掂大が明らかな24例 中 VRbは19例で，このらち18例は知能障害があった。 また先に述べたよらにこの18例はVRb 34例の53\%であ 
る. 知能障害19例中 9 例に NPH の臨床症状がそろって いた. NPH に対する shunt 手術 の適応については多く の報告がある。 Messert ${ }^{16)} ら$ NPH の症状が全部そろ い,諸検查所見が陽性のものだけに手術するとしている。 Wood $^{27}$ は RI の媨室内停滞をみる他に，腰椎穿刺で压 を下げれれば症状が改善されること, 発症から6力月以内 であることなどを規準としている，LeMay'4)，McCullough $^{15)}$ は脸空内 RI が24時間以内に消失するものの手 術成績はよくないとい5，Rudd ${ }^{21)}$ は諸条件をみたすも のの中に発作からな招短期間のものでは自然に軽快寸 る例があることを指摘し，発作後 $3 \sim 6$ 力月は経過を欢 る心゙きであるとしている，我々の9例でも，その後の経 過観察で症状が改善した2例があり，shunt 手術は７例 となった，手術成績は術後感染のためチューブを技去せ ざるをえなかった前交通動脈瘤の1例を除ききわめて有 効であった。このチューブを抜去した例は 2 年後には著 しく改善され，記憶む確かで，一応日常生活に支障がな いよ5になっている，本例は長時間を要した自然宽解例 に入れるべきであるらが，むし術後感染がなければより 早くより良く回復したであるうと思われる。また 5 年の 経過在有する脳庭動脈熘例では shunt 手術に上って知能 障害, 自発性の改善は著明であったが，四肢運動は拘祇 のため著效は得られなかった。しかし意欲の上昇に上 るリハビリテーションの効果沬みるべきすのがある。

Shunt 手術の効果は，本例の上5に年知能障害や自発 性低下に対してが早く，かつより高いよ5な印象吕他の 手術例でも見うけられている

\section{$\checkmark ま 亡 め$}

クモ膜下比血後の䯣液循環動態を RI-cisternography の形態変化と50,000カウントに要する秒数を用いたクリ アランスカーブで検討した，対象は脳動脈瘤 72例, primary SAH 16例であり, 正常对照例として 20例索選ん だ．動脈瘤群では症例によって経過観察のため数回の検 査が行われ，107回の検查回数となった.

1. RI-cisternographyi， その形態変化の時間的措移 とクリアランスカーブに上る鹃液吸收の全体像を検討す ることによって，SAH 後の㵦液偱環動態を知るのに有 用な検査である。特に NPH の疑いのあるものに溑 の検査である。

2. SAH 後 3 週以内 $の$ 急性期上り, それ以上释過し た時期が䯣液循罩動熊の変化が安定するので，本检査は $\mathrm{SAH}$ 後 3 週以上の慢性期に施行すべきである，また動 脈瘤破裂早期 患者管理加らも急性期に本検查在行うの は好ましくない。
3. 脳動脈留直達手術操作は RI-cisternography 上て の奮液循環動態にさしたる影響を与えない。

4. RI の脳空逆流はSAH後高率に起こるが，24時間 以上の停滞例はNPH を疑われ代ならない。これに両側 性の脳表クモ膜下腔閉塞があれば，その疑いは上り強く なる。

5. 知能障害や精神症状などの増悪，改善と相関して FI-cisternographyでも VRa‡VRbの変化がみられるの ミ，NPHが疑われる場合にはくり返し本検査老行い， その経過を知ることが大切である。

6. NPH の確定骖断, 手術適応の決定に対して本検查 はきわめて有用で，特にVRb で48時聞以上の脳室停滞

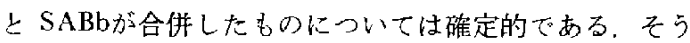
ぶない症例では saline infusion test，気媨写，跤波など 検查結果とともに総合的に判断されるばならない。

\section{文献}

1) Аввотт, M. \& Alksne, J. F.: Transport of intrathecal I $^{125}$-RISA to circulating plasma. A test for communicating hydrocephalus. Neurol 18: 870-874, 1968

2) Behrman, S., Cast, I, \& O'Gorman, P.: Two types of curves for transfer of RIHSA from cerebrospinal fluid to plasma in patients with normal pressure hydrocephalus. I Neurosurg 35: $677-680,1971$

3) Benson, D. F., LeMay, M., Patten, D. H. \& Rubens, A. B.: Diagnosis of normal pressure hydrocephalus. New Engl $J$ Med 283: 609-615. 1970

4) Chou, S. N. \& French, L. A.: Systemic absorption and urinary excretion of RISA from subarachnoid space. Neurol 5: 555-557, 1955

j) Curl, F. D., Harbert, J. C. \& McCullough, D. C.: Quantitative cisternography: An aid to diagnosis. pp 441-451, In Harbert, J. C. (ed) : Cisternography and hydrocephalus. C. C. Thomas, Springfield, Ill., 1972

6) Deland, F. H., James, A. E., Jr., Wagner, H. N., Jr. \& Hosarn, F.: Cisternography with ${ }^{169}$ Yb-DTPA. J Nucl Med 12: 683-689, 1971

7) DiChiro, G., Reames, P. M. \& Matthews, W. B., JR.: RISA-ventriculography and RISAcisternography. Neurol 14:185-191, 1964

8) Foltz, E. L. \& Ward, A. A., Jr.: Communicating hydrocephalus from subarachnoid bleeding. $J$ Neurosurg 13: 546-566, 1956

9) Galera, R. G. \& Greitz, T.: Hydrocephalus in the adult secondary to the rupture of intracranial arterial aneurysms. $J$ Neurosurg 32 : 
$634-641,1970$

10) Heivz, E. R., Davis, D. O. \& KaRP, H. R.: Abrormal isotope cisternography in symptomatic occult hydrocephalus. A correlative isotopic-neuroradiological study in 130 subjects. Radiology 95: 109-120, 1970

11) Hrinz, E. R. \& Davis, D. O.: Clinical, radiological, isotopic and pathologic correlation in normotensive hydrocephalus. pp 217-234 In Harbert, J. C. (ed) :Cisternogrphy and Hydrocephalus C. C. Thomas, Springfield, Ill., 1972,

12) Kieffer, S. A., Wolff, J. M., Prentice, W. B. \& LOKEN, M. K. Scinticisternography in individuals without known neurological disease. Am J Roentgenol 112: 225-236, 197 I

13) Kiefher, S. A., WolfF, J. M. \& Westrejch, G.: The borderline scinticisternogram. Radiology 106: 133-140,1973

14) LeMay. M. \& New, P. F. J.: Radiological diagnosis of occult normal pressure hydrocephalus. Radiology $96: 347-358,1970$

15) MaCtillolgh, D. C., Harbert, J. C., DrChiro. G. \& Ommaya, A. K.: Prognostic criteria for cerebrospinal fluid shunting from isotope cisternography in communicating hydrocephalus. Neural 20:594-598, 1970

16) Messert, B. \& Whnnamaker, B. B.: Reappraisal of the adult occult hydrocephalus. Neurol 24: 224231,1974

17) Milhorat, T. H.: Hydrocephalus and the cerebrospinal fluid. Williams \& Wilkins, Baltimore, 1972

18) Ojemann, R. G., Fisher, C. M., Adams, R. D., Sweet, W. H. \& New; P. F. J.: Further experience with the syndrome of "normal" pressure hydrocephalus. I Neurosurg 31 : 279-294, 1969

19) Ojemann, R. G.: Normal pressure hydrocelphalus. Clin Neurosurg 18: 337-370, 1971

20) Rossi, G. F., Galli, G., DiChiro, G., Maira,
G., Meglio, M. \& Troncone, L. : Normotensive hydroccphalus. The relations of pneumoencephalography and isotope cisternography to the results of surgical treatment. Acta Neurochir 30 : $69-83,1974$

21) Rudd, T. G., O'Neal, J. T. \& Nelp, W. B.: Cerebrospinal fluid circulation following subarachnoid hemorrhage. I Nucl Med 12: 61-63, 1971

22) Shulman, K., Martin, B. F., Popoff, N. \& RansohofF, J.: Recognition and treatment of hydrocephalus following spontaneous subarachnoid hemorrhage. $J$ Neurosurg 20: 1040 1049,1963

23）手场秀雉, 营沼康雄, 露無松平, 大烟正大, 稻

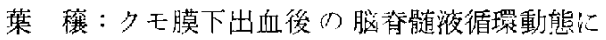
関与古研究。脳外 $3: 139-144,1975$

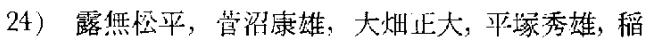
葉 鍫, 岡田治大, 星豊, 布施正明: 此常汢 水頭症に打け万Shunt 術の效果。脳外 4:149 154,1976

25) Wiltiams, J. P., Pribram, H. F, W., Lynde, R. H. \& SHARPE, A. R.: Isotope cisternography in the evaluation of patients with subarachnoid hemorrhage. $J$ Nucl Med 11:592 596, 1970

26) Williams, J. P., Lynde, R. H. \& Pribram, H. F. W.: Cisternographic changes following subarachnoid hemorrhage. pp 285-291, In Harbert, J. C. (ed) : Cisternography and hydrocephalus, C.C. Thomas, Springficleld, Ill, 1972

27) Wood, J. H., Bartiet, D., James, A. E., Jr. \& Udvarinelyi, G. B.: Normal-pressure hydrocephalus: Diagnosis and patient selection for shunt surgery. Neurol 24:517-526, 1974

28) Yasargil, M. G., Yonekawn, Y., Zumstein, B. \& STAHL, H.: Hydrocephalus following spontancous subarachnoid hemorrhagc. Clinical feature and treatment. $J$ Neurosurg 39: $474 \cdot 479$, 1973 